\title{
Insight into the factors effecting exchange rates and types of exchange rate regime followed by various countries.
}

\author{
Simanta Das
}

\section{Introduction:}

There are different factors that impact exchange rates. Exchange rates are highly unpredictable and they need to be monitored very closely to understand the change. Exchange rates are often used as indicator to determine nation's health. There are various market forces that effects exchange rates which is often determined by its level of demand and supply. Foreign Exchange policy is influenced by reversal of capital flows which causes balance of payments issues and makes currency volatile. Traders usually rely on two fundamental form of analysis in stock market viz fundamental analysis and technical analysis. However unlike companies countries donot have balance sheets and hence other parameters are used to determine countries health.

\section{Economic Indicators:}

Government releases various reports at specified times to highlight the country's performance. These reports are released to various agencies which tells them of nations health. Effect of these reports are similar to that of SEC filings, earning reports that can have on the securities market. Any deviations from the standard can effect price and volume movements. Equity investors usually rely on four economic indicators to determine the state of the economy which eventually impacts the market and also the exchange rate of the currency.

\section{Gross Domestic Product (GDP):}

It is considered the widest measure of a country's economy which represents the total market value of all goods and services produced in a country during a given year. Traders usually rely on two reports that are issued earlier viz the advance report and the preliminary report. Significant changes between these reports can cause considerable currency volatility.

\section{Retail Sales:}

This report usually tells us about the total receipt of retail stores across the country. Consumer spending pattern based on seasonality can be derived from this report. Any revision on the advanced retail sales report can impact the volatility of the currency which in turn effects the exchange rates.

\section{Industrial Production:}

In this report changes in industrial production, mines and utilities within the country are highlighted. Traders usually looks at the changes in utility production and its changes. Effect of any significant changes in the utility production has an impact on the currency.

\section{Consumer Price Index:}

This report indicates the changes in prices of various products. When compared with nation's exports this report can indicate if nation is making profit or loss on its product and services. Traders usually see this report to judge the strength of the currency when compared to its exports.

In selecting the exchange rate system (currency regime) government is usually guided by the following criteria:

-- The current level of competitiveness of the economy;

-- The balance of payments and financial system;

-- State foreign exchange reserves;

-- Economic and political climate in the country.

There are two main foundations of monetary exchange rate regimes in the world practice. Stabilization of the economy can be carried out through one of these regimes:

1) A mechanism of fixing or pegging the national currency exchange rate against another currency or basket of currencies;

2) Regime, opposite to the first, based on freely floated currency exchange rates.

The evolution of currency regimes in the world practice shows a trend of gradual transition from fixed exchange rate regimes to the more flexible exchange rate regime. The core mechanism of currencies with flexible exchange regimes is a real demand and supply of the national currency in the domestic and foreign markets.

Fixed exchange rate system has the following advantages: 
- Quantitatively predictable (promotes trade and stimulates the flow of capital);

- increases high confidence in the monetary policy, decreases government expenses spent to control inflation;

- stabilized inflation, reduces inflationary expectations in the labour market and financial markets.

As international experience has shown, fixed exchange rate operates best in the country with the following conditions in the economy:

- A small and open economy under the influence of a strong currency (or currencies of major trading partners);

- A significant portion of foreign trade is carried out with a country whose currency is pegged to the national currency (for a stable trade environment for domestic producers);

- Macroeconomic policies oriented at keeping the inflation at the level of the country, which currency attached to (in case of low rate of inflation);

- Structural reforms are being implemented in the country, and there is a real independence of the Central Bank.

Floating exchange rate allows you to maintain competitiveness and quickly adapts to external shocks and impulses, and the most important - the Government is relieved of the functions of determining an appropriate exchange rate. Despite these advantages, the regime of free floating exchange rate is not without flaws:

- if the foreign exchange market is characterized by low capacity, then some few large transactions can undermine existing state;

- this regime can ensure the effectiveness of monetary policy in regulation by the state, as well as taking financial and fiscal measures;

- it can be unattractive to foreign investors and trading partners because of uncertainty in this regime;

- There is a threat to government manipulation (-dirty floating\|), thus undermining the credibility of market agents

- if there is large speculative capital flows in the country, the determination of exchange rates greatly limits the monetary and financial independence.

Main conditions for implementation the floating exchange rates are existence of developed financial market, integration with the international system, the interchangeability of domestic and foreign monetary assets. Nevertheless, despite the absence of these factors, many countries have shifted to a floating rate regime. The reasons for this are imbalances in balance of payments, minor amounts of official foreign exchange reserves to support the fixed rate and desire to block the "black" exchange markets.

\section{References:}

[1]. Lane, Philip, 1999: What Determines the Nominal Exchange Rate? Some Cross-Sectional Evidence, The Canadian Journal of Economics / Revue canadienne d'Economique, Vol. 32, No. 1. pp. 118-138.

[2]. MacDonald, Ronald, 1997: What Determines Real Exchange Rates: The Long and Short of It, IMF Working Paper 97/21

[3]. Obstfeld, Maurice, 1995: International currency experience: new lessons and lessons relearned, Brookings Papers on Economic Activity 1, 119-196

[4]. Obstfeld, Maurice, and Kenneth Rogoff, 1995: The mirage of fixed exchange rates, Journal of Economic Perspectives (1996) Foundations of International Macroeconomics, Cambridge, MA, MIT Press.

[5]. Rogoff, Kenneth, 1985: The optimal degree of commitment to a monetary target, Ouarterly Journal of Economics 100, 1 169-190

[6]. Romer, David, 1993: Openness and inflation, Quarterly Journal of Economics 107, 869-904

[7]. Rudiger Dornbusch, 1973: Exchange rates and inflation. Published by MIT Press, Cambridge. 